\title{
Evaluation of chitosan gel with $1 \%$ silver sulfadiazine as an alternative for burn wound treatment in rats $^{1}$
}

\author{
Avaliação do gel de quitosana contendo sulfadiazina de prata $1 \%$ como alternativa para o \\ tratamento de queimaduras em ratos
}

\author{
I Fellow Specialization degree, Department of Pharmacy, UnP, Natal, Brazil. \\ ${ }^{\text {II }}$ Biologist, Department of Biological Sciences, UnP, Natal, Brazil. \\ ${ }^{\text {III }} \mathrm{PhD}$, Chairman and Head, Department of Surgery, UFRN, Natal, Brazil. \\ ${ }^{\text {IV }}$ Master, Assistant Professor, Department of Pharmacy, UnP, Natal, Brazil.
}

Ednaldo Gomes do Nascimento ${ }^{\mathrm{I}}$, Tarcísio Bruno Montenegro Sampaio ${ }^{\mathrm{II}}$, Aldo Cunha Medeiros ${ }^{\mathrm{III}}$, Eduardo Pereira de Azevedo ${ }^{\mathrm{IV}}$

\begin{abstract}
Purpose: Evaluation of the rheological, biological and therapeutic properties of a new topical formulation consisting of chitosan gel containing 1\% silver sulfadiazine, as an alternative for the treatment of burn wounds. Methods: An experimental study was done with 21 Wistar rats divided into three groups. Group I was treated with chitosan gel without the antimicrobial, group II was treated with chitosan gel with $1 \%$ silver sulfadiazine and group III was treated with commercially available 1\% silver sulfadiazine cream. Results: Due to its pseudoplastic characteristic and good bioadhesiveness, the chitosan gels showed a satisfactory retention time over the wounds. No statistical difference was found in the amount of drug released from the chitosan gel and commercially available cream, as well as in the healing time among the groups. Wounds treated with chitosan gel with silver sulfadiazine showed a higher fibroblast production and a better angiogenesis than in the other groups, which are important parameters on the evolution of the healing process. Conclusion: The topical use of chitosan gel in association with silver sulfadiazine ameliorated the neovascularization and inflammatory reaction in burn wounds. This new formulation showed advantageous rheological properties and efficient release of the drug.
\end{abstract}

Key words: Chitosan. Silver Sulfadiazine. Gel. Wound Healing. Rats.

\section{RESUMO}

Objetivo: Avaliar as propriedades reológicas, biológicas e terapêuticas de uma nova formulação de uso tópico, a partir de um gel de quitosana, contendo sulfadiazina de prata a 1\%, no tratamento de queimaduras. Métodos: Foi realizado estudo experimental com 21 ratos Wistar distribuídos em três grupos de sete animais. As queimaduras dos animais do grupo I foram tratadas com gel de quitosana sem antimicrobiano, o grupo II foi tratado com gel de quitosana contendo sulfadiazina de prata $1 \%$ e o grupo III foi tratado com creme de sulfadiazina de prata $1 \%$, comumente utilizado no tratamento de queimados. Resultados: Devido às características pseudoplásticas e à boa bioadesividade, os géis de quitosana apresentaram um tempo de retenção satisfatório sobre as feridas. A liberação da sulfadiazina de prata, bem como o tempo de cicatrização, não foram estatisticamente diferentes. Feridas tratadas com o gel de quitosana contendo sulfadiazina de prata apresentaram uma maior produção de fibroblastos e uma melhor angiogênese, comparando-se com os outros grupos, fatores que indicaram uma maior evolução no processo de cicatrização. Conclusão: O uso tópico do gel de quitosana com sulfadiazina de prata a 1\% melhorou a neovascularização e a reação inflamatória em queimaduras e essa nova formulação mostrou boas propriedades reológicas associadas a eficiente liberação do fármaco.

Descritores: Quitosana. Sulfadiazina de prata. Cicatrização de Feridas. Ratos.

${ }^{1}$ Research performed at Department of Pharmacy, Potiguar University (UnP) and Department of Surgery, Federal University of Rio Grande do Norte (UFRN), Natal, Brazil.

\section{Introduction}

After a severe burn, the injured surface becomes vulnerable to the bacteria, due to the loss of the protective skin barrier. High levels of bacteria in the burn wound can decrease the availability of growth factors, which can retard the healing process $^{1,2}$. Thus, delivering antibiotics locally as an adjunctive treatment method to systemic dosing can reduce overall serum concentration of antibiotic, while increasing the local concentration to bactericidal levels ${ }^{3}$. Among the topical antibiotics, silver sulfadiazine presents good tolerability by the patient, has low toxicity, good penetrability in the scar tissue and a broad spectrum of activity against most microorganisms, particularly the Gram-negatives. For these reasons, silver sulfadiazine represents the topical antimicrobial of choice for burn treatment ${ }^{1,4}$. Usually, it is available as a cream in a concentration of $1 \%{ }^{3}$. 
Chitosan is a linear copolymer of $\beta(1=>4)$ linked 2-acetamido-2-deoxy- $\beta$-D-glucopyranose and 2-amino-2-deoxy$\beta$-D-glycopyranose, easily obtained by deacetylation of chitin, an abundant polysaccharide found in nature as a component of exoskeletons of crustaceans and insects. Chitosan is reported to be biocompatible, biodegradable and non toxic, having some biomedical properties such as healing accelerator, antifungal, hemostatic, antimicrobial and analgesic ${ }^{5,6}$. Several studies have shown the activity of chitosan in the healing process, where it enhanced the infiltration of inflammatory cells in the injured area. Moreover, chitosan stimulates the activity of macrophages and fibroblasts on the process of wound healing, resulting in a more pronounced formation of granulation tissue. There have been studies showing that chitosan gel formulations accelerated wound healing ${ }^{7,8}$. However, no study has been done using chitosan gel combined with silver sulfadiazine. Therefore, a comparison with a standard burn wound treatment such as $1 \%$ silver sulfadiazine cream seems to be relevant.

In this study, the preparation of chitosan gel containing $1 \%$ silver sulfadiazine is reported. Rheological properties of the obtained gel and its ability to control the release of silver sulfadiazine were investigated. Additionally, the effect of the chitosan gels (with and without silver sulfadiazine) on healing of burn wounds on rats was compared with the commercially available 1\% silver sulfadiazine cream. Histopathologic studies were performed on the epithelized wounds to investigate the presence of fibroblasts, as well as the neovascularization.

\section{Methods}

\section{Preparation of the chitosan gels}

Chitosan (degree of deacetylation of $87.5 \%$ ) was dissolved in acetic acid $2 \%(\mathrm{v} / \mathrm{v})$, yielding a final concentration of $3.5 \%(\mathrm{w} / \mathrm{v})$. In order to form the gel, formaldehyde was added into the chitosan solution in a ratio of $0.002 \mathrm{~g}$ per gram of chitosan. In addition, glycerin was added in a ratio of $0.2 \mathrm{~g}$ per gram of chitosan. The mixture was stirred until the gel was completely formed. A known amount of the obtained gel was used to incorporate $1 \%$ of silver sulfadiazine. This concentration was achieved by adding $0.01 \mathrm{~g}$ of silver sulfadiazine per gram of chitosan gel. After homogenization, the gels were stored in closed containers at ambient temperature until use.

\section{Rheological properties of the gels}

The rheological properties of the chitosan gel, with and without silver sulfadiazine, were determined using a Brookfield viscometer, model R/S Rheometer, where the viscosity of the gels was determined under a constant increase in the shear rate. Then, the viscosity was plotted against the shear rate and the rheological properties were evaluated.

\section{Release studies}

In order to investigate the ability of the chitosan gel to control the release of silver sulfadiazine, the amount of this drug released from the gel was compared to the amount released from a commercially available silver sulfadiazine $1 \%$ cream. Thus,
$1 \mathrm{~g}$ of each sample was put in a dialysis sac (porous size of $12000 \mathrm{Da}$ ) and immersed in individual flasks containing $25 \mathrm{~mL}$ of Ringer solution. The solution was gently stirred and after 1, 2, 8, 24 and 48 hours an aliquot was withdrawn from the solution and the amount of drug released from the gel or cream was determined by spectrophotometry at $256 \mathrm{~nm}$. In order to keep the volume constant, aliquots of fresh Ringer solution was replaced after each sampling. The absorbance results were converted to concentration $(\mathrm{mg} / \mathrm{mL})$ using a calibration curve. All the analysis was done in triplicate.

\section{Burn wound model}

Twenty one male Wistar rats weighing $321 \pm 51 \mathrm{~g}$ were used in the in vivo studies. The protocol for this study was approved by the Institutional Animal Care Committee, and it was performed in accordance with the guidelines from Brazilian College of Animal Experimentation. The animals were housed in individual cages with water and food (rodent chow) ad libitum. Each rat was previously anesthetized with intraperitoneal injection of thiopental $(20 \mathrm{mg} / \mathrm{kg})$ with ketamine $(20 \mathrm{mg} / \mathrm{kg})$. The dorsum hair on the area to be burned was shaved and then waited $24 \mathrm{hrs}$ before infliction to minimize local inflammation. Then, the burn infliction was made by holding a $1.5 \mathrm{~cm}^{2}$ aluminum square, previously heated at $100^{\circ} \mathrm{C}$, over the exposed skin for 5 seconds. A haste weighing $200 \mathrm{~g}$ was connected to the aluminum square before infliction. Therefore, the pressure applied over the skin (due to the weight of the haste) was the same for all animals. Postoperative pain was treated with tenoxicam; $10 \mathrm{mg} / \mathrm{kg}$ was given i.m. to the rats once a day for three days.

\section{Burn treatment}

The animals were divided into three groups. The wounds of group 1 rats $(n=7)$ were treated with chitosan gel without silver sulfadiazine, group II rats $(n=7)$ were treated with chitosan gel with silver sulfadiazine $1 \%$ and group III rats $(n=7)$ were treated with the commercially available silver sulfadiazine $1 \%$ cream. Groups I and II were submitted to applications of gel every 48 hours and group III was submitted to daily applications of the silver sulfadiazine $1 \%$ cream. Between each application of gel or cream, the wounds were cleaned with sterile $0.9 \%$ saline solution. The wounds were kept opened (without bandages) during the entire experiment. The animals were observed daily in the morning and the time taken to reach complete epithelialization was considered as the healing time (in days).

\section{Histopathologic study}

After the wound was completely epithelialized, fullthickness biopsy $(2 \times 3 \mathrm{~cm})$ was taken. Biopsies included adjacent skin, wound margin and epithelialized wound. The samples were stored in $10 \%$ formaldehyde for $48 \mathrm{hs}$ prior to inclusion in paraffin. After that, each histological sample was stained using hematoxylineosin and Masson's trichrom staining methods. The quantitative analysis was done with a light microscope (magnification 100x), Olympus model BX50 and the histopathologic data were evaluated by the software Image ProPlus, Media Cybernetics, version 4.0 for Windows. The inflammatory cells, fibroblast and new blood vessels were quantified. 


\section{Statistical analysis}

The statistical analysis of the results was performed by the unpaired Student's $t$-test. The level of significance was set at $\mathrm{p}<0.05$.

\section{Results}

\section{Rheological properties of the gel}

In this work, chitosan gel was formed by cross-linking its free amine (NH2) groups with formaldehyde. Figure 1 shows a plot of the viscosity $(\eta)$ of the chitosan gel, with and without silver sulfadiazine, against the shear rate. The viscosity of both gels varied according to the change in the shear rate, which indicates a non-Newtonian type of fluid. The presence of silver sulfadiazine increased the viscosity of chitosan gel at zero shear rate $(\mathrm{p}<0.05)$. However, once the shear rate increased, the difference between the viscosity of both gels was not significant $(p>0.05)$. In both cases, the viscosity decreased gradually as the shear rate increased.

\section{Release studies}

The ability of the chitosan gel to control the release of silver sulfadiazine was compared to the commercially available cream. Both formulations had exactly the same concentration of the drug. The amount of silver sulfadiazine released from both the chitosan gel and the commercially available cream is presented as the concentration of this drug in the release medium plotted against time (Figure 2).

According to Figure 2, the release of silver sulfadiazine followed the same profile for both samples, where the amount of drug released increased over time. However, there was no significant difference $(\mathrm{P}>0.05)$ between the amount released from the gel and cream. In both cases, the concentration of silver sulfadiazine released was above the Minimum Inhibitory Concentration (MIC) of $18 \mathrm{mg} / \mathrm{L}$ established by Modak and Fox ${ }^{9}$ for Pseudomonas aeruginosa, even in the first hour of experiment.

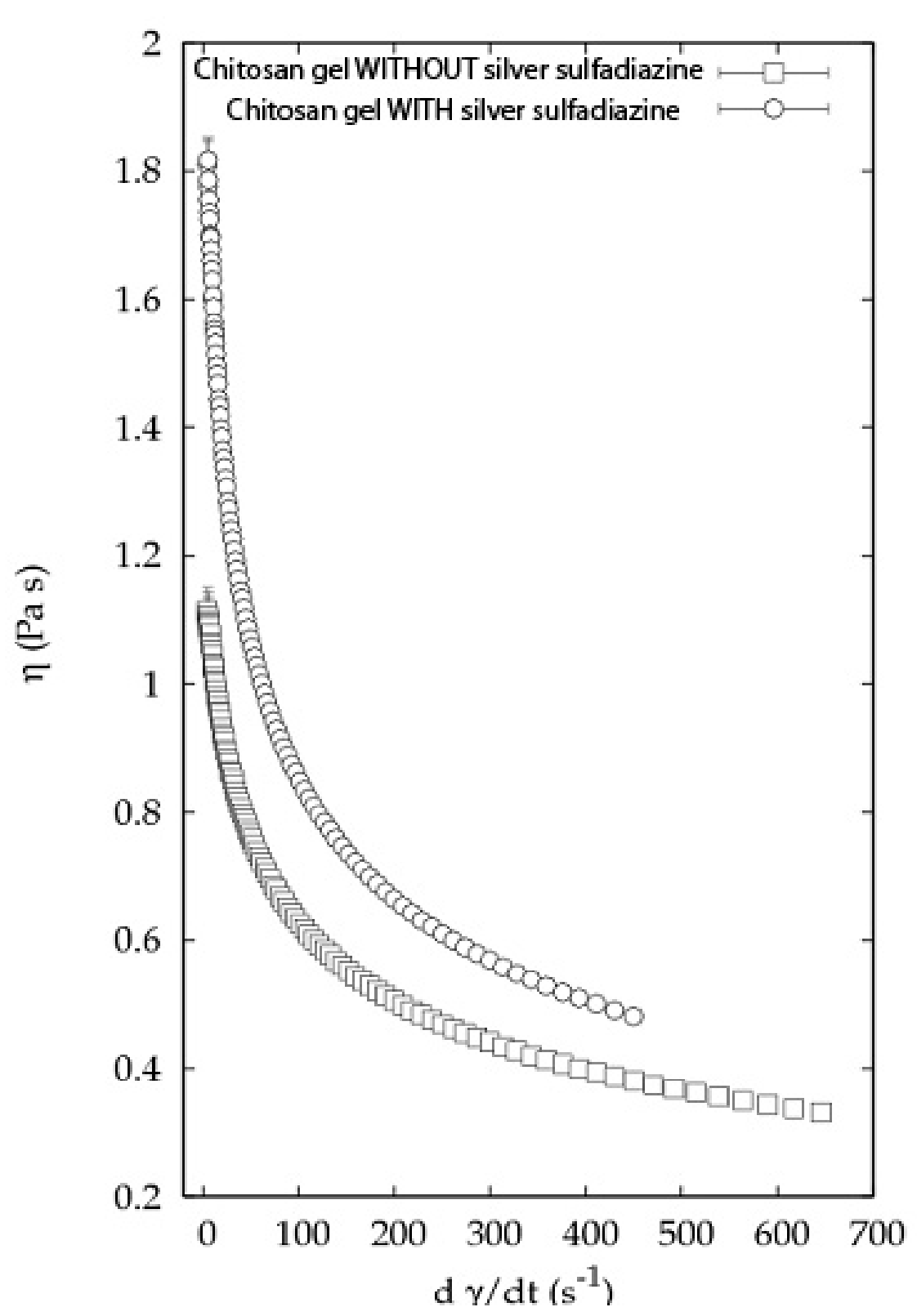

FIGURE 1 - Viscosity $(\eta)$ versus shear rate of chitosan gel without (squares) and with silver sulfadiazine (circles) 


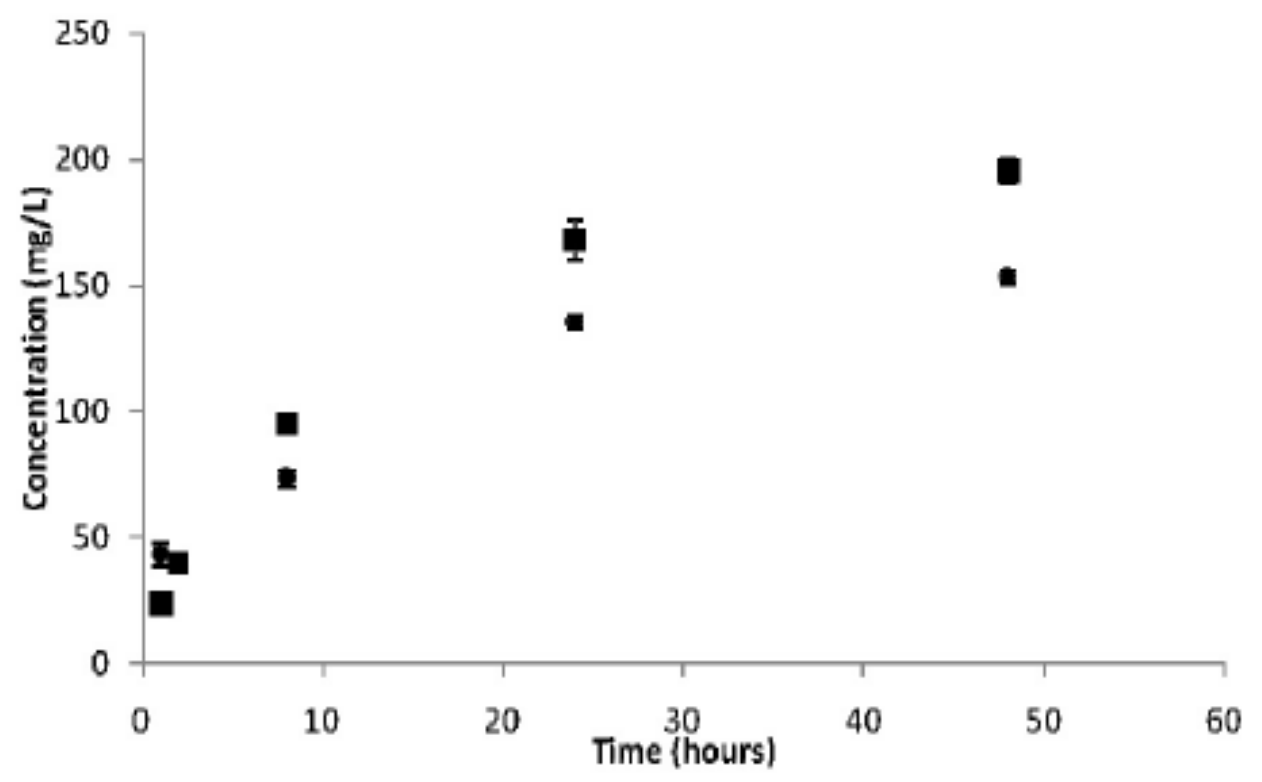

FIGURE 2 - Release of silver sulfadiazine from chitosan gel (circle) and commercially available cream (square). $n=3$. Error bar: standard deviation. No difference was observed comparing the two formulations $(\mathrm{p}>0.05)$

\section{Healing time}

After five seconds in contact with the dorsum of the rats, the previously heated $\left(100^{\circ} \mathrm{C}\right)$ aluminum square caused a second degree burn. The animals were treated with applications of chitosan gel (with or without the antibiotic) or silver sulfadiazine cream directly over the wounds without covering them with bandages. The chitosan gel was able to form a bioadhesive film over the wound after the evaporation of the solvent. Table 1 shows the healing time of the wounds from group I, II and III.

TABLE 1 - Time required for epithelization (healing time) in days

\begin{tabular}{cccc}
\hline \multirow{2}{*}{ Rat's number } & $\begin{array}{c}\text { HEALING TIME (days) } \\
\text { I - Chitosan gel without } \\
\text { silver sulfadiazine }\end{array}$ & $\begin{array}{c}\text { II - Chitosan gel with } \\
\text { silver sulfadiazine }\end{array}$ & $\begin{array}{c}\text { III - Silver } \\
\text { sulfadiazine Cream }\end{array}$ \\
\hline 1 & 23 & 26 & 26 \\
2 & 28 & 26 & 29 \\
3 & 38 & 28 & 29 \\
4 & 38 & 43 & 32 \\
5 & 44 & 49 & 26 \\
6 & 44 & 32 & 36 \\
7 & 42 & 27 & 32 \\
Average & $36.7 \pm 8.18$ & $33.0 \pm 9.27$ & $30.0 \pm 3.61$ \\
\hline
\end{tabular}

$\mathrm{p}>0.05$ comparing the groups 
In our study, no differences on the healing time were observed among the groups ( $\mathrm{p}>0.05)$. This shows a potential advantage of the chitosan gels over the commercially available silver sulfadiazine cream, since the former was applied every 48 hours, whereas the last was applied every 24 hours. On the other hand, the presence of silver sulfadiazine in the chitosan gel does not seem to contribute to the epithelization process.

\section{Histopathologic study}

After the complete epithelization, the scar and adjacent tissue were submitted to the histopathologic study. Table 2 shows the number of inflammatory cells of each group related to the total number of cells in a specific area. The percentage of inflammatory cells in each group did not change significantly $(\mathrm{p}>0.05)$.

TABLE 2 - Number of inflammatory cells and the percentage of such cells related to the total number of cells in a specific area

\begin{tabular}{cccc}
\hline Groups* & $\begin{array}{c}\text { Total number of cells in } \\
\text { specific areas }\end{array}$ & $\begin{array}{c}\text { Number of inflammatory } \\
\text { cells }\end{array}$ & $\%$ \\
\hline I & 5483.3 & 317.9 & 5.8 \\
II & 3491.1 & 218.0 & 6.2 \\
III & 4356.7 & 253.0 & 5.8 \\
\hline
\end{tabular}

*= I: chitosan gel without silver sulfadiazine, II: chitosan gel with silver sulfadiazine and III: commercially available silver sulfadiazine $1 \%$ cream. $p>0.05$ comparing the 3 groups.

Concerning the histological findings, the presence of fibroblasts was clearly shown in all rats. However, the wounds treated with chitosan gel with silver sulfadiazine showed a higher number of fibroblasts compared to the other wounds. In addition, the formation of new blood vessels was more evident in the wounds treated with chitosan gel, meaning that the angiogenesis was remarkable in the group treated with silver sulfadiazine chitosan gel.

\section{Discussion}

By definition, gels are tridimensional polymeric networks that can retain a significant amount of water within their structures and swell without dissolving ${ }^{10}$. This means that they have the ability to absorb exudates, which keeps moisture on the wound surface. Besides, gels have high water vapor and oxygen permeability, as well as mechanical properties that resemble physiological soft tissues ${ }^{11}$. Therefore, gels could be considered as ideal pharmaceutical forms to treat burn wounds. In this work, chitosan was the material used to form the gels due to its good gel forming property, biodegradability, biocompatibility and nontoxicity. On the other hand, silver sulfadiazine, the most used topical antimicrobial agent to treat burn wounds, was entrapped in the chitosan gel. The viscosity of the gels (with and without silver sulfadiazine) decreased gradually as the shear rate increased, indicating a pseudoplastic or shear thinning behavior. This can be advantageous, since the gel would become more fluid while it is being spread over the injured surface, leading to an easier and less painful application. In addition, the viscosity would probably increase when the stress is ceased (shear rate equal to zero), avoiding the gel to flow from the site of application.
In our findings, the chitosan gel was able to form a bioadhesive film over the wound after the evaporation of the solvent (second day of treatment). Chitosan gel has been reported to have a strong tissue adhesiveness, being more efficient than fibrin glue in sealing air leakages from pinholes on isolated small intestines, aorta and trachea specimens ${ }^{12}$. Due to this bioadhesiveness, the film sticks to the wound protecting it against the bacteria entrance. In addition to the physical protection, the gel should release the antimicrobial efficiently in order to successfully decrease the bacterial levels. In the present study, the amount of silver sulfadiazine released from the chitosan gel was above the MIC for Pseudomonas aeruginosa, one of the most common and dangerous pathogenic microorganism responsible for infections in burn wounds, from the first hour of experiment. Although the release characteristics of the gel might be different from the bioadhesive film, the chitosan gel efficiently released the antimicrobial for 48 hours. Since microorganisms proliferate rapidly in burn wounds, the burst followed by a sustained release of silver sulfadiazine from the chitosan gel would play an important role in maintaining low levels of the wound flora. Thus, the longer contact of the bioadhesive chitosan film to the wound surface together with the effective release of silver sulfadiazine for 48 hours could eliminate the need of frequent application. This is the reason why chitosan gels were applied every 2 days, instead of the usual daily application. Even being applied less frequently than the commercially available silver sulfadiazine cream, the healing time was statistically the same for all groups.

One of the most important stages in the wound healing process is the inflammatory stage, where the inflammatory cells clean foreign agents in the wound area ${ }^{13}$. Therefore, the presence of inflammatory cells indicates that the healing process and tissue 
repair are occurring ${ }^{14,15}$. The percentage of inflammatory cells in each group did not vary significantly $(\mathrm{P}>0.05)$. This finding probably indicates that chitosan gel is more efficient than the commercially available silver sulfadiazine cream, since the gel was applied less frequently than the cream during the course of the experiment. According to our histopathologic results, a synergic effect between chitosan and silver sulfadiazine for the fibroblasts and blood vessels formation was observed. Kjolseth et al. ${ }^{16}$ examined the effect of six topical wound agents (bacitracin, sodium hypochloride, silver nitrate, silver sulfadiazine, mafenide acetate and povidone-iodine) on neovascularization in mice. According to the authors, complete wound neovascularization occurred earliest in mice treated with povidone-iodine and silver sulfadiazine, compared to the other agents and the control group. Since the vessels supply the wound with oxygen, immunoglobulins and white blood cells, the neovascularization represents an important process in defending the wound against infection. Therefore, the chitosan gel containing silver sulfadiazine 1\% seems to be advantageous to treat burn wounds.

\section{Conclusion}

The topical use of chitosan gel in association with silver sulfadiazine at $1 \%$ ameliorated the neovascularization and inflammatory reaction in burn wounds. In addition, this new formulation showed advantageous rheological properties and efficient release of the drug.

\section{References}

1. Ward RS, Saffle JR. Topical agents in burn and wound care. Phys Ther. 1995; 75:526-38.

2. Robson MC, Mannari RJ, Smith PD, Payne WG. Maintenance of wound bacterial balance. Am J Surg. 1999;178:399-402.

3. Monafo WW, West MA. Current treatment recommendations for topical burn therapy. Drugs. 1990;40:364-73.
4. Azevedo EP, Saldanha TDP, Navarro MVM, Raffin FN. Mechanical properties and release studies of chitosan films impregnated with silver sulfadiazine. J Appl Polym Sci. 2006;102:3462-70.

5. Rinaudo M. Chitin and chitosan: properties and applications. Prog Polym Sci. 2006;31:603-32.

6. Prabaharan M. Review paper: chitosan derivatives as promising materials for controlled drug delivery. J Biomater Appl. 2008;23:5-36.

7. Ishihara M, Ono K, Sato M, Nakanishi K, Saito Y, Yura H. Acceleration of wound contraction and healing with a photocrosslinkable chitosan hydrogel. Wound Repair Regen. 2001;9:513-21.

8. Alemdaroglu C, Degim Z, Celebi N, Zor F, Ozturk S, Erdogan D. An investigation on burn wound healing in rats with chitosan gel formulation containing epidermal growth factor. Burns. 2006;32:319-27.

9. Modak S, Fox C. Synergistic action of silver sulfadiazina and sodium piperacillin on resistant Pseudomonas aerugionosa in vitro and in experimental burn wound infections. J Trauma. 1985;25:27-31.

10. Wang T, Turhan M, Gunasekaran S. Selected properties of $\mathrm{pH}-$ sensitive, biodegradable chitosan-poly(vinyl alcohol) hydrogel. Polym Int. 2004;53:911-8.

11. Sezer AD, Cevher E, Hatipoglu F, Ogurtan Z, Bas AL, Akbuga J. Preparation of fucoidan-chitosan hydrogel and its application as burn healing accelerator on rabbits. Biol Pharm Bull. 2008;31:2326-33.

12. Ono K, Saito Y, Yura H, Ishikawa K, Kurita A, Akaike T. Photocrosslinkable chitosan as a biological adhesive. J Biomed Mater Res. 2000;49:289-95.

13. Ueno H, Yamada H, Tanaka I, Kaba N, Matsuura M, Okumura M. Accelerating effects of chitosan for healing at early phase of experimental open wound in dogs. Biomaterials. 1999;20:1407-14.

14. Medeiros AC, Ramos AMO, Dantas Filho AM, Azevedo RCF, Araujo, FLFB. Tratamento tópico de queimaduras do dorso de ratos com acido hialuronico. Acta Cir Bras. 1999;14:203-7.

15. Ueno H, Nakamura F, Murakami M, Okumura M, Kadosawa T, Fujinag T. Evaluation effects of chitosan for the extracellular matrix production by fibroblasts and the growth factors production by macrophages. Biomaterials. 2001;22:2125-30.

16. Kjolseth D, Frank JM, Barker JH, Anderson GL, Rosenthal AI, Acland RD. Comparison of the effects of commonly used wound agents on epithelialization and neovascularization. J Am Coll Surg. 1994;179:305-12.

Conflict of interest: none Financial source: none

\section{Correspondence:}

Eduardo Pereira de Azevedo

Avenida Jaguarari, 5100/83

59064-500 Natal-RN Brazil

azevedoep@hotmail.com

Received: April 08, 2009

Review: June 12, 2009

Accepted: July 29, 2009

\section{How to cite this article}

Nascimento EG, Sampaio TBM, Medeiros AC, Azevedo EP. Evaluation of chitosan gel with 1\% silver sulfadiazine as an alternative for burn wound treatment in rats. Acta Cir Bras. [serial on the Internet] 2009 Nov-Dec;24(6). Available from URL: http://www.scielo.br/acb 